\title{
LAPS-Heuristik Learning Model Toward Students' Mathematical Creative Thinking Ability
}

\author{
Dwi Ayu Ningsih ${ }^{1)}$, Hella Jusra ${ }^{1),}$, , Ayu Faradillah ${ }^{1)}$, Fitri Alyani ${ }^{1)}$, and Fery \\ Firmansah $^{2)}$ \\ ${ }^{1)}$ Department of Mathematics Education, University of Muhammadiyah Prof. DR. HAMKA, Jakarta, 11360, \\ Indonesia \\ ${ }^{2)}$ Department of Mathematics Education, University of Widya Dharma, Klaten, 12220, Indonesia \\ a) Corresponding author: hella.jusra@uhamka.ac.id
}

\begin{abstract}
This study aims to determine whether or not there is an effect of the Logan Avenue Problem Solving (LAPS) Heuristic learning model on students' mathematical creative thinking abilities. This research is quantitative research and uses the quasi experimental research method. The study population included all VII grade students of junior high school and the sample studied was 76 students. The sampling technique uses cluster random sampling method. Data collection techniques using mathematical creative thinking ability instruments. The results of this study can be concluded that there is a slight influence of the Logan Avenue Problem Solving (LAPS)-heuristics model of the mathematical creative thinking skills of the students.
\end{abstract}

Keywords: LAPS-Heuristik learning model, mathematical creative thinking ability

\section{INTRODUCTION}

One of the mathematics abilities required by the pupils is the ability to think creatively. This is because students can express their ideas on the problems freely given in accordance with the knowledge that has been obtained previously. The ability to think creatively is one of the important things at this time because it can make students become more flexible, open and easy to adapt to various problem situations in daily life [1]-[4]. During the learning process, it is best to support the activities of students to explore the understanding and understanding that they have gained in solving problems so that students are accustomed to thinking creatively. In addition, various problems need to be given to be solved by students. This is intended to provide an opportunity for students to find their own solutions and the answers can be different from those already taught.

The indicators that measure the ability of mathematical creative thinking are fluency, flexibility, elaboration, and originality [5]. These four indicators can develop and build one's knowledge in creating new ideas. The smooth thinking can be defined from the number of responses of students to solve problems. From the responses of the students there are still a variety of problem solving strategies with flexibility aspects. The student response is said to be genuine (original) if quirky, unusual, and is only done by a few. The response is said to be detailed if the procedure is coherent, logical, clear, and derived [6], while according to Guilford [5] find traits that characterize creative thinking abilities, namely: 
a. Fluency

The ability to think now includes the ability to trigger ideas, solve problems and provide answers to problems, provide many examples or statements relating to concepts in certain situations.

b. Flexibility

The ability to think flexibly includes the ability to generate ideas, provide varied answers, use a variety of completion strategies, give examples related to the concept and look for many different alternative solutions.

c. Originality

The ability to think original or new things includes the ability to give birth to new expressions, unique, unusual thoughts to express new, unique or unusual statements.

d. Elaboration

Detailing the ability to think includes to explain in detail, enrich and develop ideas or products, add or detail in detail the situation so that it becomes more interesting, or answer certain mathematical situations.

The ability to think mathematically is the ability of creative thinking processes to express ideas and develop it so it can create something new. As for other opinions the definition of each indicator of the ability to think creatively as follows [7]

Table 1. Indicator of Mathematical Creative Thinking Ability

\begin{tabular}{|c|l|l|}
\hline No & \multicolumn{1}{|c|}{ Indicator } & \multicolumn{1}{c|}{ Definition } \\
\hline 1 & Current thinking (fluency) & $\begin{array}{l}\text { a. Generate many ideas, answers, problem solving or } \\
\text { questions } \\
\text { b. Give lots of ways or suggestions for doing various } \\
\text { things } \\
\text { c. Always think of more than one answer. }\end{array}$ \\
\hline 2 & Flexible thinking (flexibility) & $\begin{array}{l}\text { a. Generate ideas, answers, or questions that vary. } \\
\text { b. Can see a problem from different points of view. Look } \\
\text { for many alternatives or different directions. }\end{array}$ \\
\hline 3 & The original thinking (originality) & $\begin{array}{l}\text { a. Being able to think out to new and unique expressions } \\
\text { b. Thinking about unusual ways to express themselves } \\
\text { c. Able to make unusual combinations of parts or elements }\end{array}$ \\
\hline 4 & Thinking in detail (elaboration) & $\begin{array}{l}\text { a. Able to enrich and develop an idea or product } \\
\text { b. Add or detail the details of an object, idea or situation so } \\
\text { that it becomes more interesting. }\end{array}$ \\
\hline
\end{tabular}

In accordance with what was explained by Mursalin [8] that the ability to think creatively affects one's ability to solve problems. In line with the opinion of Carson [9] which states that the ability to think creatively can be developed through problem solving. Students can give ideas, thus creating new things. Mathematical creative thinking ability of students is currently not optimal due to several factors, but the main factor is teaching and learning activities that are less supportive of students developing their ideas. One solution is to provide treatment during the learning process by applying a supportive learning model to improve mathematical critical thinking skills, namely the Logan Avenue Problem Solving (LAPS)-Heuristic model.

The LAPS-Heuristic learning model is a method that provides flexibility in solving the given problems. Meanwhile, to give a pleasant impression while sharpening the creativity of students, this learning model helps mind mapping [10]. The LAPS learning model is a set of guide questions in problem solving.
LAPS usually uses the question word what is the problem, is there an alternative, is it useful, what is the solution, and how to do it [11], while the European are general suggestions that help an individual to make progress toward its solution [12].

Furthermore, Polya [13] defines heuristics as a way of helping to find solutions. According Suryani and Iqbal

[14] Logan Avenue Elementary School (Emporia, Kansas) proposed a heuristic to solve problems in mathematics, including: (1) what is the problem ? (2) what are the alternatives? (3) what are the advantages or disadvantages? (4) what is a solution? (5) how well is it working? Furthermore, the heuristic is called Logan Avenue Problem Solving (LAPS)-Heuristic.

In the learning process students are actively involved, so when they get a problem, students can build creative traits that is understanding, formulating, finding and reflecting on their own ways how these problems are resolved, in addition to helping students in building 
learning independence. Creative thinking skills can be assessed through the presentation of problem solving with various types [15]. This in solving problems, students can use the step of thinking with the heuristic method. This refers to the opinion of Carson [9] "Problem Solving is a heuristic".

\section{METHOD}

The purpose of this study was to determine the effectiveness of the application of the Logan Avenue Problem Solving (LAPS)-Heuristic learning model to students' mathematical creative thinking ability. This type of research is quantitative research. The design in this study is the randomized posttest-only control design. For the sampling technique using cluster random sampling, two classes of the population were selected. The two classes were given different treatments, namely the experimental class by applying the LAPS-Heuristic model and the control class by not applying the LAPS-Heuristic model. Both of these classes measure students' mathematical creative thinking abilities after the treatment is given. The number of samples in this study was 76 with the number of students in the experimental class and the control class were 38 students.

The instrument of mathematical creative thinking ability is in the form of a description given to two classes. The results of mathematical creative thinking ability test results are data that is processed in hypothesis testing. Before the mathematical creative thinking ability test data is processed, there are scoring guidelines that are modified according to this research from Bosch [16] as follows:

Table 2. Guidelines for Scoring Mathematical Creative Thinking Ability

\begin{tabular}{|c|c|c|}
\hline Measured aspects & Reaction to problems / problems & Score \\
\hline \multirow[t]{5}{*}{ Fluency } & Not answering / giving wrong answers & 0 \\
\hline & Give ideas that are not relevant to problem solving & 1 \\
\hline & Provide ideas that are relevant but the solution is wrong & 2 \\
\hline & Give more than one relevant idea but the answer is still wrong & 3 \\
\hline & Give more than one relevant idea and the answer is correct & 4 \\
\hline \multirow[t]{5}{*}{ Elaboration } & Not answering / giving wrong answers & 0 \\
\hline & There was an error in the answer and not the details & 1 \\
\hline & $\begin{array}{l}\text { There was an error in the answer but it was accompanied by a lack of } \\
\text { detail }\end{array}$ & 2 \\
\hline & $\begin{array}{l}\text { There was an error in the answer but it was accompanied by a detailed } \\
\text { breakdown }\end{array}$ & 3 \\
\hline & Give correct and detailed answers & 4 \\
\hline \multirow[t]{5}{*}{ Flexibility } & Not answering / giving wrong answers & 0 \\
\hline & Giving answers to answers is only one way and giving wrong answers & 1 \\
\hline & $\begin{array}{l}\text { Providing answers is only one way but the calculation process and the } \\
\text { results are correct }\end{array}$ & 2 \\
\hline & $\begin{array}{l}\text { Give answers in more than one way but the results are wrong because } \\
\text { of mistakes in the calculation process }\end{array}$ & 3 \\
\hline & $\begin{array}{l}\text { Give answers in more than one way, and the calculation process and } \\
\text { the results are correct }\end{array}$ & 4 \\
\hline \multirow[t]{5}{*}{ Originality } & Not answering / giving wrong answers & 0 \\
\hline & Give answers in their own way but cannot be understood & 1 \\
\hline & $\begin{array}{l}\text { Give answers in your own way, the calculation process has been } \\
\text { directed but not finished }\end{array}$ & 2 \\
\hline & $\begin{array}{l}\text { Give answers in their own way, but there are errors in the calculation } \\
\text { process so the results are wrong }\end{array}$ & 3 \\
\hline & $\begin{array}{l}\text { Give answers in their own way, the calculation process and the results } \\
\text { are correct }\end{array}$ & 4 \\
\hline
\end{tabular}




\section{RESULTS AND DISCUSSION}

The results of the study after the treatment was given with the LAPS-Heuristic learning model to measure students' mathematical creative thinking ability, the data description is obtained as follows:

Table 3. Statistic Descriptive

\begin{tabular}{|c|c|c|c|c|c|}
\hline \multirow{2}{*}{ Group } & \multicolumn{5}{|c|}{ Result } \\
\cline { 2 - 6 } & $\mathbf{n}$ & $\mathbf{x}_{\min }$ & $\mathbf{x}_{\max }$ & $\bar{x}$ & $\mathbf{s}$ \\
\hline Experiment & 38 & 8 & 27 & 18.47 & 5.45 \\
\hline Control & 38 & 5 & 26 & 16.08 & 5.32 \\
\hline
\end{tabular}

The result from table 3 indicate that the average score of students' mathematical creative thinking ability in the experimental class is greater when compared to the control class. However, to ensure whether the hypothesis is true or not, it will be tested mathematically. From the prerequisite testing that has been carried out, the hypothesis testing is carried out using the t-test and it is concluded that the effectiveness of the application of LAPS-Heuristic learning model on the creative thinking ability of students. The percentage of each indicator of students' mathematical creative thinking ability

Table 4. Percentage of Students' Mathematical Creative Thinking Indicator

\begin{tabular}{|l|c|c|}
\hline \multirow{2}{*}{$\begin{array}{c}\text { Indicators of } \\
\text { mathematical creative } \\
\text { thinking skills }\end{array}$} & $\begin{array}{c}\text { Pxperiment } \\
\text { Group }\end{array}$ & Control Group \\
\cline { 2 - 3 } & $65.13 \%$ & $62.5 \%$ \\
\hline Fluency & $64.14 \%$ & 47.37 \\
\hline Flexibility & $72.37 \%$ & $73.03 \%$ \\
\hline Originality & $65.46 \%$ & $54.61 \%$ \\
\hline Elaboration & \multicolumn{2}{|c|}{} \\
\hline
\end{tabular}

From table 4, it can be seen that in the experimental class that is applied the LAPS-Heuristic learning model, the highest indicator percentage of the four types of indicators of the ability of mathematical thinking creative is original at $72.37 \%$. This percentage is $0.66 \%$ smaller than the control class, but in this class the percentage in flexible indicators is smaller than the others, which is $47.37 \%$.

In the experimental class, the three indicators, namely fluency, flexibility, and elaboration are owned by most of the students in explaining the answers to the questions given. In contrast to the control class, more students were quite capable of expressing their ideas in answering questions.

Based on the results of the study, it was obtained that the students' mathematical creative thinking ability became better after the implementation of the LAPSHeuristic learning model than students who did not apply the LAPS- Heuristic learning model Students who get the LAPS-Heuristic model can more quickly understand the concepts of mathematical material and are able to develop mathematical creative thinking abilities because in the learning process students are more active in generating ideas to answer problems, as well as providing ideas that vary from given problems. Participants students are also accustomed to identify every challenge to then take the alleged decision. This situation allows students to have a better experience in finding a solution to a mathematical problem. This research as stated in the previous section, provides an illustration that LAPS -Heuristic learning model can provide better motivation for students' mathematical creative thinking abilities, so that it can be used as a space to develop ideas and be able to apply them in everyday life. This is in accordance with the results of research conducted by [3] that by applying the problems of everyday life in learning can make students connect and apply them to generate new ideas according to student knowledge, so it is necessary to create a learning atmosphere that can develop creative thinking skills.

At the time of the learning process takes place, students understand the problems given, accept ideas between students who can provide the entire learning process that is carried out. Based on the ideas that have been expressed, then several questions arise in solving the problem that has been given to solve the problem from the problem. The final result in the learning process is the concept learned by students to create solutions and develop ideas against the challenges that have been given. When it is finished, the students submit their solutions to other students in front of the class and conclude the material they have learned. 


\section{CONCLUSIONS}

The effectiveness of the LAPS-Heuristic learning model makes students' mathematical creative thinking skills better. Students can provide answers that vary from the problem given.

From the results of research and discussion, the average mathematical creative thinking ability of students who applied the LAPS-Heuristic learning model was higher than those who did not apply the LAPS-Heuristic learning model. This causes that the effectiveness of applying the LAPS-Heuristic learning model to the mathematical creative thinking ability of students.

\section{REFERENCES}

[1] W. Wahyu, A. Suryatna, and Y. S. Kamaludin, "The suitability of william's creativity indicators with the creativity-based worksheet for the junior high school students on designing simple distillation tool," J. Eng. Sci. Technol., vol. 13, no. 7, pp. 1959-1966, 2018.

[2] L. Puspitasari, A. In'am, and M. Syaifuddin, "Analysis of Students' Creative Thinking in Solving Arithmetic Problems," Int. Electron. J. Math. Educ., vol. 14, no. 1, pp. 49-60, 2018, doi: 10.12973/iejme/3962.

[3] V. Švecová, L. Rumanová, and G. Pavlovičová, "Support of Pupil's Creative Thinking in Mathematical Education," Procedia - Soc. Behav. Sci., vol. 116, pp. 1715-1719, 2014, doi: 10.1016/j.sbspro.2014.01.461.

[4] N. Si. Aisyah and L. S. Zanthy, "Analisis Kemampuan Berpikir Kreatif Matematis dan Self Concept Siswa Mts Pada Materi Himpunan," J. Educ., vol. 01, no. 03, pp. 252-259, 2019, doi: 10.24127/ajpm.v7i1.1316.

[5] U. Munandar, "Kreatifitas Pengembangan Anak Berbakat," Jakarta: Rineka Cipta, 2009.

[6] D. K. Fardah, "Analisis Proses dan Kemampuan Berpikir Kreatif Siswa dalam Matematika Melalui Tugas Open-Ended," Kreano J. Mat. Kreat., vol. 3, no. 2, pp. 91-99, 2012, doi: 10.15294/kreano.v3i2.2616.

[7] F. E. Williams, "Workshops on the Use and Adaptation of New Media for Developing Creativity; National Schools Project. Final Report.," 1968.

[8] Mursalin, "Menumbuhkan Kemampuan Berpikir Kreatif Melalui Pengembangan Konten Buku Matematika Berbasis Pembelajaran Model Treffinger," ResearchGate, no. May 2016, pp. 017, 2016.

[9] J. Carson, "A Problem With Problem Solving:
Teaching Thinking Without Teaching Knowledge," Math. Educ., vol. 17, no. 2, pp. 714, 2007.

[10] Amidi and F. A. Zahra, "The students' activity profiles and mathematic problem solving ability on the LAPS-Heuristic model learning," Unnes $J$. Math. Educ., vol. 7, no. 1, pp. 72-77, 2018, doi: 10.15294/ujme.v7i1.17087.

[11] A. Shoimin, Model Pembelajaran Inovatif dalam Kurikulum 2013. Yogyakarta: Ar-Ruzz Media, 2014.

[12] D. B. McLeod and A. H. Schoenfeld, "Mathematical Problem Solving," Coll. Math. J., 1987, doi: 10.2307/2686811.

[13] G. Polya, "How To Solve It: A New Aspect of Mathematical Method." Princeton University of America, USA, 1957.

[14] Suryani and Iqbal, "Pengaruh Model Pembelajaran Logan Avenue Problem Solving (Laps-Heuristik) Terhadap Hasil Belajar Siswa Kelas VII SMP Negeri 2 Langsa," J. Ilm. Pendidik. Mat. AL-QALASADI, vol. 2, no. 2, pp. 50-56, 2018.

[15] A. Bahar and C. June Maker, "Cognitive backgrounds of problem solving: A comparison of open-ended vs. closed mathematics problems," Eurasia J. Math. Sci. Technol. Educ., vol. 11, no. 6, pp. 1531-1546, 2015, doi: 10.12973/eurasia.2015.1410a.

[16] D. Ismaimuza, "Kemampuan berpikir kritis dan kreatif siswa SMP melalui pembelajaran berbasis masalah dengan strategi konflik kognitif," Disertasi (tidak diterbitkan), 2010. 